\title{
Study of superoxide dismutase's expression in the colon produced by azoxymethane and inositol hexaphosfate's paper, in mice ${ }^{1}$
}

\author{
Estudo da expressão de superóxido dismutase no cólon produzida por \\ azoximetano e o papel do inositol hexafosfato, em ratos
}

\author{
Eva Glória Abrão Siufi do Amaral², Djalma José Fagundes ${ }^{3}$, Guido Marks², Celso Massachi Inouye ${ }^{2}$ \\ 1. Department of Surgery of Federal University of Mato Grosso do Sul, Brazil \\ 2. Associate Professor, Department of Surgery of Federal University of Mato Grosso do Sul,, Brazil. \\ 3. Associate Professor Department of Surgery of Federal University of Sao Paulo, Brazil.
}

\begin{abstract}
Purpose: To investigate the expression of superoxide dismutase (SOD), with use of antioxidant inositol hexaphosfate, in the presence of the carcinogen azoxymethane, in FCA of colon rats. Methods: Wistar rats $(n=48)$ were distributed in four groups of 12 mice. Divided in control $(n=12)$; with azoxymethane administration AOM ( $n=12)$; administration of IP6 ( $n=12)$ and with administration of IP6/AOM $(n=12)$. The subcutaneous administration of azoxymethane happened in the week 3 and 4 of the experiment, in dose $20 \mathrm{mg} / \mathrm{Kg}$, weekly; and administration of IP6 to $1 \%$ in water of drinking for 6 weeks in the group 3 and 4. The identification of the expression SOD-1 was accomplished through the quantification imunohistochemistry by the image processing attended by computer in crypts and focus of aberrant crypts in right colon. Results: The group control presented expression of SOD1, on average 16,0\%; group AOM, 26,7\%; group IP6, 16,9\%; group IP6/AOM, 20,9\%. Variance analysis among the groups, was calculated 0,0078. Conclusion: The azoxymethane increase expression SOD1, while inositol hexaphosphate decreases in a significant way the expression of SOD1 promoted by the administration of the carcinogen azoxymethane.
\end{abstract}

Key words: Colon. Superoxide Dismutase. Phytic Acid. Carcinogens. Azoxymethane. Rats.

\section{RESUMO}

Objetivo: Investigar a expressão de superóxido dismutase, com uso de antioxidante inositol hexafosfato, na presença do carcinógeno azoximetano em FCA de cólon de ratos. Métodos: Quarenta e oito ratos Wistar, distribuídos em 4 grupos, divididos em controle $(n=12)$; com administração de azoximetano AOM ( $n=12)$; administração de IP6 (n=12) e com administração de IP6/AOM (n=12). A administração subcutânea de azoximetano aconteceu na semana 3 e 4 do experimento, em dose 20mg/Kg, semanal; e administração de IP6 a 1\% em água de beber durante 6 semanas no grupo 3 e 4 . A identificação da expressão SOD1 foi realizada através da quantificação imunohistoquimíca pelo processamento de imagem assistida por computador em criptas e focos de cripta aberrante em cólon direito. Resultados: O grupo controle apresentou expressão de SOD1, em média 16,0\%; grupo AOM, 26,7\%; grupo IP6, 16,9\%; grupo IP6/AOM, 20,9\%. Análise de variância entre os grupos calculou-se 0,0078. Conclusão: A expressão de SOD-1 mostrou aumento significativo na presença de azoximetano e quando administrou-se IP6 concomitante houve diminuição na expressão de SOD1 promovido pela administração do carcinógeno azoximetano.

Descritores: Colo. Superóxido Dismutase. Àcido Fítico. Carcinógeno. Azoximetano. Ratos.

\section{Introduction}

The prevalence and the incidence of the colon cancer are variable among different human populations. Epidemic evidences indicate that those differences are influenced strongly by the geographical area, culture and alimentary habit. It has been originating chemoprevention strategies in development ${ }^{1}$. A correlation inversely proportional it was found among the fiber content in the diet and the frequency of colon cancer. The fact lifts the hypothesis that diets with high fiber tenor somehow can work as protecting to the emergence of neoplasics intestinals ${ }^{2}$. The inositol hexaphosphate (IP6) it is a protecting element found in the alimentary diet; having been studied extensively in animals, being considered as an agent anti-cancer; present in vegetables, wheat flour and derived of soya ${ }^{3}$. IP6 in the diet could suppress oxidizers that damage the intestinal epithelium and neighboring cells. The accumulation of data in animal model of disease indicates that the dietary supplement with IP6 can provide significant protection against colon cancer induced experimentally. He would act as antioxidant when excluding the generation of species reactivates of oxygen (ERO) through the metals quelation ${ }^{4}$. The cellular consumption of oxygen is essential for the 
fosforilation during the generation of adenosine trifosfato (ATP) in the mitochondria. This cellular metabolism takes the production of species reactivate of oxygen, including the radical superoxide $\left(\mathrm{O}_{2}^{-}\right)$and the peroxide of hydrogen $\left(\mathrm{H}_{2} \mathrm{O}_{2}^{-}\right)$. The accumulation of species reactivates of oxygen results in stress oxidative, and if no corrected, it can take to I harm biomolecular of the membrane lipid, proteins and of $\mathrm{DNA}^{2}$. The paper of ERO in the organized progression of the carcinogenesis is evident for the fact demonstrated that several free radicals, in different combinations, increase the conversion of benign papilom in carcinoma and it effectiveness can be related to the type of radicals produced in the system biologic ${ }^{6}$. Studies demonstrated that IP6 reduces the index cellular mitotic working as cytostatic; being absorbed instantly by the treatment gastrointestinal ${ }^{6}$. The azoxymethane is recognized as carcinogen agent and inductor of Focus of Aberrant Crypt (FCA) in animal model of disease. FCA is had as a reliable parameter in the cólon ${ }^{7,8}$ carcinogenesis. A antioxidant key enzyme implicated in the regulation of damages tissue mediated by ERO is the superoxide dismutase extracellular (SOD-EC). She is found at the head office extracellular of fabrics and it is positioned to prevent cellular damages and tissue unchained by ERO produced extracellular. Besides, it is probable that she represents an important paper mediating events of signaling apoptotic induced by the oxide nitric ${ }^{9}$. Malignant cells are in general more active than normal cells in the production of radicals free from oxygen under conditions of stress oxidative and they are like this more vulnerable to the damages provoked by agents that generate these species reactivate of oxygenic ${ }^{10}$, there fore it is waited that there is an increase of SOD-EC in these conditions. The oxidation increased in cells tumor induces these cells use it more enzymes oxidizers as the superoxide dismutase to eliminate the species reactivate of oxygenic ${ }^{11}$. In some cancer types, as the one of breast, the activity of $\mathrm{CuZn} \mathrm{SOD} \mathrm{is} \mathrm{diminished}{ }^{12}$ while in pre-cancerous lesions as of colon and of stomach it one find increased. Being taken into account that the inositol hexaphosphate (IP6) it is an antioxidant agent that promotes the protection of the epithelium intestinal ${ }^{13}$ and that the method of evaluating it protection in the human being still is not explained is that it decided to do this study in animal model of carcinogenesis, with azoxymethane use that is promoter of focus of aberrant crypt (FCA); with the quantitative evaluation of the expression of SOD through study imunohistochemistry.

\section{Methods}

The present study has been approved by the Committee of Ethics in Research of the Hospital Sao Paulo - UNIFESP - EPM, under the register number 28/05, ratified by the Committee of Ethics in Animals of the Universidade Federal de Mato Grosso do Sul-UFMS, under the register number 61/04. Sample 48 (N were used) mice Wistar (Rattus norvegicus), males, with 08 weeks of age, medium weight of 15626 grams, original of Central Bioterio of UFMS. The research happened at the Laboratory of Experimental Carcinogenesis, enclosure to Central Bioterio of UFMS. The animals, in number of four, were housed in polypropylene boxes with cover of galvanized wire (standard size for 05 animals). They stayed during the whole period, besides the 7 days for adaptation before the experimental procedures, exposed under artificial light (130 to $3251 \mathrm{ux}$ ) with cycles ligth/dark of 12:00 hours, temperature medium $24 \pm 2{ }^{\circ} \mathrm{C}$, with medium humidity of $52,8 \%$ and fed with ration (Nuvilab CR1) and water filtered comfortable. The distribution of animals in the groups and inside of the own group it was for draw. The identification of the animals was accomplished through tattoo in the tail. It identified the groups from 1 to 4. Inside of each group the animals were individualized by alphabetical order of A to M. Group I ( $n=12)$, control; Group II $(n=12)$, with administration of AOM; Group III $(n=12)$, administration IP6; Group IV ( $\mathrm{n}=12)$, administration of IP6 and AOM. It was weekly accompanied the evolution pondered of the animals.

\section{Administration of substances:}

IP6 (Sigma, product P3168, formulation $\mathrm{C}_{6} \mathrm{H}_{6} \mathrm{O}_{24} \mathrm{P}_{6} \mathrm{Na}_{12}$ ) - $1 \mathrm{mg}$ in $100 \mathrm{ml}$ of filtered water (solution to the $1 \%$ ); administration road: oral in the water of drinking. AOM (Sigma, product A9517, formulation $\mathrm{C}_{2} \mathrm{H}_{6} \mathrm{~N}_{2} \mathrm{O}$ ) - 20mg/Kg of a $0,1 \mathrm{ml}$ solution (100mg of AOM) diluted in $49,9 \mathrm{ml}$ of solution of chloride of sodium to $0,9 \%(2 \mathrm{mg} / \mathrm{ml})$; administration road: daily subcutaneous injection. Saline solution of chloride of sodium $0,9 \%-10 \mathrm{ml} / \mathrm{Kg}$; administration road: daily subcutaneous injection.

\section{Periods of application of the drugs:}

Group I: saline solution, third and fourth weeks, 1x/ week. Group II: IP6 no administered; AOM, third and fourth weeks, 1x/week. Group III: IP6, of the first to the sixth week; AOM no, administered; saline solution, third and fourth weeks, 1x/week. Group IV: IP6 of the first to the sixth week; AOM, third and fourth weeks, 1x/week. The mice were identified, heavy and euthanasia was accomplished with thiopental administration in the dose of $150 \mathrm{mg} . \mathrm{kg}-1$, saw intra-peritoneal. Death verification. Retired of the piece for the study. The mouse was positioned in number decubitus, being proceeded medium laparotomy; the area ileum-cecum was identified; being then solitary in block the right colon and terminal ileum. It has been prepared of the operative piece for study. It took place opening of the colon in the border anti-mesenteric and wash of the mucous membrane with saline solution $0,9 \%$, to proceed, it was made resection of segment of right colon with extension of $1 \mathrm{~cm}$ of length to leave and distal the area ileum-colic, noticing the colon scrap among rigid double mold for rectification of the wall of the colon; the piece obtained like this was immersed in formol lampooned to $10 \%$, for 24 hours. Preparation of blocks andsheets. It took place inclusion in paraffin (staying identification of the sample); diereses with microtome in parallel cut the mucous surface (sagital) to the wall of the colon, interesting 4 micrometers of thickness and, the cuts were stuck in glass sheet for the histological processing. The processing imunohistochemistry was accomplished with the use of antibody primary anti-SOD1 (SantaCruz Biotechnology Inc) dilution 1:500. Antibody secondary antimouse (Dako, product KO-609, dilution 1:1500). Discloser of color DAB-diamino benzedrine (Dako, product K34767- 
1, dilution 1:20) and expression obtaining SOD1 in the brown coloration. It took place the quantification of SOD1 through image processing attended by computer with Software ImageLab's use, in ten images of crypts captured in each animal and quantification of the density of brown color (using the filter RGB, color of blue bottom, interval of color from 0 to 147) that corresponds to the area fraction captureT2 with the expression SOD1, for the total area capture-T1 (Figure 1).

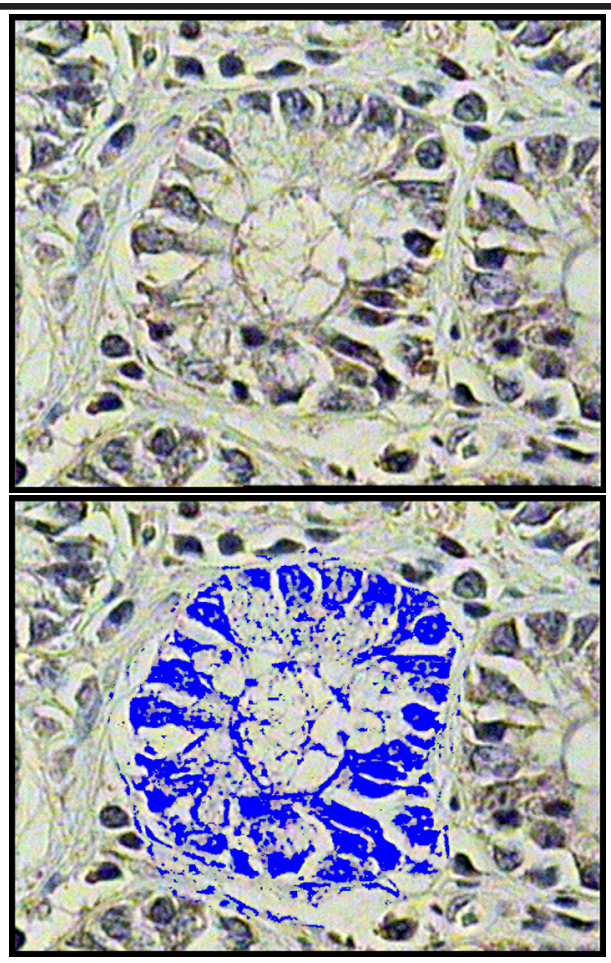

FIGURE 1 - Capture image exemplification the quantification area with the expression SOD1 (area blue).

The analysis of the data was processed being used the statistical program Epi-info. Used tests ANOVA for comparison of the medium weight of the animals of the beginning at the end of the experiment. For analysis of the result variance test for expression of SOD1 and it was obtained $p=0,0000$ in graphic 1 . The results of the comparison of the averages are described in the graphic 1 .

\section{Results}

It was verified under process imunohistochemistry medium expression of group I (control) $16,0 \pm 3,7$; group II (AOM) 26,7 $\pm 3,5$; group III (IP6) 16,9 $\pm 3,1$; group IV (IP6/ AOM) $20,9 \pm 3,3$ conformed Figure 3 . The graphic above demonstrates the antioxidant effect of IP6. The comparison among the groups I and II is significant, among the group I and III it doesn't have significances. Among the groups I and IV; II and IV; III and IV, it shows alteration in the significances demonstrating that the association with IP6 takes the expression of SOD1 similar to the group controls. The expression of higher SOD1 was in the group II (AOM) confirming the effect of the azoxymethane.

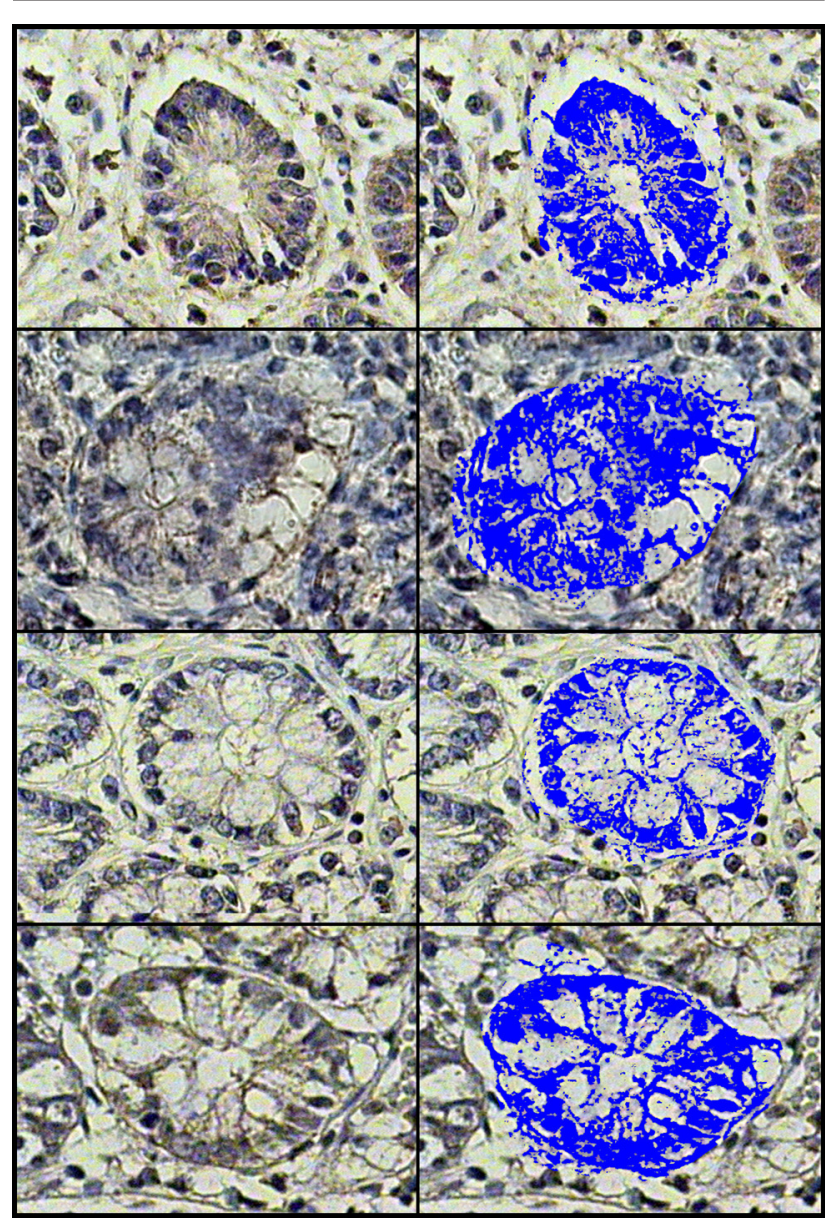

FIGURE 2 - Photography characterizing focus of crypt aberrant, in cut sagital, submitted a procedure imunohistochemistry with expression SOD1 brown color. Imageprocessing attended by computer and visualization of the expression SOD1 in the blue coloration. The image corresponds representative sample of the average in each group.

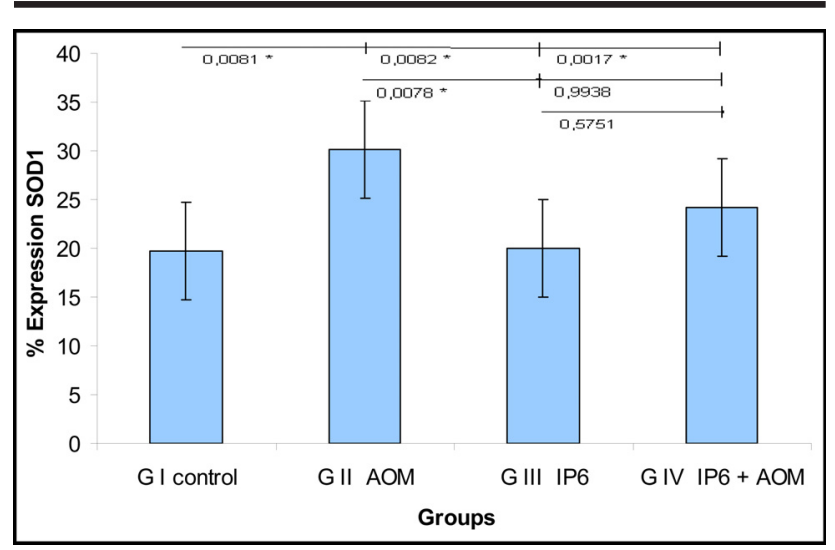

FIGURE 3 - Results imunohistochemistry. * Significance $p<0,05$

\section{Discussion}

Stress oxidative results from a relative unbalance to the capacity antioxidant/oxide ${ }^{14}$. Multiple forms exist of inducing the production of stress oxidative and variability exists in the alterations of biological markers; such like $\mathrm{SOD}^{11,15} \mathrm{MnSOD}^{16} \mathrm{GSH}$ (glutathione) ${ }^{17}$ and Catalase ${ }^{18}$. They 
are not identified link SOD1 and administration of AOM. In this experiment the chosen animal was the mouse, already studied as animal model of disease; taking the induction of focus of aberrant crypt (FCA $)^{19}$ resulting in increase in the incidence of rectal lap. The recognition of FCA as final point in the carcinogenesis of the cólon ${ }^{20}$ uses the following histological alterations: the) alteration in the opening of the lumen; b) thickened epithelium and c) crypts with larger extensions that the adjacent ones. The period of this experiment was of 6 weeks and the carcinogenesis of short duration promoted by chemical carcinogen (AOM) it is recommended by IARC of the World Organization of Health $^{13}$. Confirmed in experiment with mice, significant increase in the frequency of FCA in right colon with azoxymethane administration and significant reduction of FCA when the inositol hexafosfate is administered with the azoxymethane ${ }^{21}$. Under physiologic conditions, SOD is indeed capable to decompose the anion superoxide in peroxide of oxygen and di-oxygen. According to Frederiks and Bosch $^{22}$ (1997) until this date no technique was available to locate activity of SOD in woven. With the use of that methodology it was found the high activity of the enzyme not only in cells liver endothelium and kidney, but also in liver hepatocytes, miocytes of the heart, flat and grooved cells of muscle, cells of the pancrea, cells epithelium of the renal tubule, and cells epithelium of the small intestine and colon. These discoveries are in agreement with the data of obtained imunohistochemistry using antibodies against $\mathrm{Cu} / \mathrm{Zn}$ and Mn-SOD. The present method allows the analysis of all the three types of activity of known SOD $(\mathrm{Cu} / \mathrm{Zn}, \mathrm{Mn}$, and extracellular) in different woven and compartments cellulars ${ }^{23,24}$. What was evaluated in this experiment IP6 is been would be capable to act as protecting in the presence of the carcinogen (AOM) through the evaluation imunohistochemistry of this protecting enzyme that is the superoxide dismutase. In this study they were appraised 4 groups of animals, in the group I (it controls) there was administration of saline solution; in the group II (AOM) azoxymethane was injected in dose of $20 \mathrm{mg} / \mathrm{kg}-1$ in accordance model animal of disease; in the group III (IP6) it administered inositol hexaphosphate in the water of drinking for 6 weeks and saline solution in the weeks 3 and 4 and the group IV (AOM+IP6) it is the group experiment, inositol was offered in water of drinking and azoxymethane (AOM) in the weeks 3 and 4 . The daily attendance of the animals didn't reveal significant alteration of weight corporal), suggest that the drugs didn't have harmful effect. The imunohistochemistry was accomplished with the use of the antibody primary anti-SOD1 and it quantification was made through the image process attended by the program ImageLab, in ten images captured in each animal. The results of SOD1 in this work were: group I: $16,0 \pm 3,7$; group II: 26,7 \pm 3 ,5 group III: $16,9 \pm 3,31$ and group IV: $20,9 \pm 3,3$. When it is compared the group I and II, I and IV has significant alteration and the group I and III doesn't have significant alteration; the comparison among the other groups had significant alteration. With these results it was demonstrated that the azoxymethane took to the significant increase of the expression of SOD1; in the presence of inositol hexaphosphate there was the significant decrease of the expression of SOD1.
The inositol hexaphosphate (IP6) it is an antioxidant that acts when inhibiting the generation of species reactivate to the oxygen of $\mathrm{H}^{-2} \mathrm{O}^{-2}$ resulting in cancer chemoprevention. In this experiment it sought the inositol hexaphosphate to be evaluated it neutralizes the expression of SOD1 in the stress oxidative, in this case provoked by the carcinogen azoxymethane. The hiperexpress of SOD1 was interpreted as low production of free radicals. SOD is decreased in some types of tumors and one find increased in tumors of the treatment gastrointestinal according to studies of Magalova et al. ${ }^{12}$ erythrocytes, Beno et al. ${ }^{25}$. In study Shamsuddin ${ }^{6}$ demonstrated that IP6 + AOM took the significant decrease of mitoses in intestinal cells. The statistical study of this experiment was the variance test due to homogeneity of the groups. When the group I is compared (I group normal), with the group II (AOM), with the group IV (AOM + IP6) a significant difference exists, but with the group III (IP6), difference significant statistics doesn't exist. The expression of SOD1 was shown high in the group II. Already experiments ${ }^{9}$ exist showing that the overestimate of oxidizer production, not always it results in the increase of the antioxidant defense and that the elevation of the antioxidant capacity not always it correlates with degree protection. These results demonstrate that AOM took to the significant increase in the expression of SOD1 and in the presence of IP6 there was decrease of the expression of SOD1. This work has importance for the fact of allowing evaluating stress oxidative through quantitative study of SOD1 in mice; doesn't tend other equal until the date of execution; also for the possibility of dietary orientation to the risk populations and for the opening of new studies.

\section{Conclusion}

The experiment evidenced that the azoxymethane increases in a significant way the expression of superoxide dismutase- 1 and that concomitant administration of inositol hexaphosphate reduces significant the expression of SOD1 in focus of aberrant crypt in right colon.

\section{References}

1. Owen RW. Dietary and chemopreventive strategies. Recent Results Cancer Res 1998; 146: 195-213.

2. Hileman EA, Achanta G, Huang P. Superoxide dismutase: an emerging target for cancer therapeutics. Expert Opin Ther Targets. 2001;5(6):697-710.

3. Fox CH, Eberl M. Phytic acid (IP6), novel broad spectrum anti-neoplastic agent systematic review. Complemente Ther Med. 2002;10(4):229-34.

4. Hileman EO, Liu J, Albitar M, Keating MJ, Huang P. Intrinsic oxidative stress in cancer cells: a biochemical basis for therapeutic selectivity. Cancer Chemother Pharmacol. 2004;53(3):209-19.

5. Seril DN, Liao J, Yang GY, Yang CS. Oxidative stress and ulcerative colitis-associated carcinogenesis: studies in humans and animal models. Carcinogenesis. 2003;24(3):353-62. 
6. Shamsuddin AM. Metabolism and cellular functions of IP6: a review. Anticancer Res. 1999;19(5A):3733-6.

7. Magnuson BA, Bird RP. Resistance of aberrant cript foci to apoptosis induced by azoxymethane in rats chronically fed cholic acid. Carcinogenesis 1994;15:1459-69.

8. Kawamori T, Tanaka T, Hara A, Yamahara J, Mori H. Modifying effects of naturally occurring products on the development of colonic aberrant crypt foci induced by azoxymethane in F344 rats. Cancer Res. 1995;55(6):1277-82.

9. Fattman CL, Schaefer LM, Oury TD Extracellular superoxide dismutase in biology and medicine. Free Radic Biol Med. 2003;35(3):236-56.

10. Das U. A radical approach to cancer. Med Sci Monit. 2002;8(4):79-92.

11. Oberley TD, Oberley LW. Antioxidant enzyme levels in cancer. Histol Histopathol. 1997;12(2):525-35.

12. Magalova T, Bella V. Brtkova A. Beno I. Kudlackova M. Volkovova K. Copper, zinc and super oxide dismutase in precancerous bening diseases and gastric, colorectal and breast cancer. Neoplasma. 1999;46(2):100-4.

13. Marks G, Estudo da frequência de foco de cripta aberrante na carcinogênese de cólon com administração de hexafosfato de inositol, em ratos. [Dissertação de Mestrado]. Universidade Federal de São Paulo; 2004.

14. Oberley, Teny D. Am J Pathol. 2002;160(2):403-8.

15. Owen RW, Spiegelhalder B, Bartsch H. Phytate, reactive oxygen species and colorectal cancer. Eur J Cancer Prev. 1998;7(S2):41-54.

16. Rohrdanz E., Kahl R. Alterations of antioxidant enzyme expression in response to hydrogen peroxide. Free Radical Biol. Med. 1998;24:27-38.

17. Wispe J. R., Clark J. C., Burnhans M. S., Kropp K. E., Kofhagen T. R., Whitsett J. A. Synthesis and processing of the precursor for human mangano-superoxide dismutase. Biochim. Biophys Acta. 1989;994:30-6.
18. Ambrosone CB, Freudenheim JL, Thompson PA, Bowman E, Vena JE, Marshall JR, Graham S, Laughlin R, Nemoto T, Shields PG. Manganese superoxide dismutase (MnSOD) genetic polymorphisms, dietary antioxidants, and risk of breast cancer. Cancer Res. 1999;59(3):602-6.

19. Kohen R, Nyska A. Oxidation of biological systems: oxidative stress phenomena, antioxidants, redox reactions, and methods for their quantification. Toxicol Pathol. 2002;30(6):620-50.

20. Davis CD, Feng Y. Dietary copper, manganese and iron affect the formation of aberrant crypts in colon of rats administered 3,2'-dimethyl-4-aminobiphenyl. J Nutr. 1999;129(5):1060-7.

21. Midorikawa K, Murata M, Oikawa S, Hiraku Y, Kawanishi S. Protective effect of phytic acid on oxidative DNA damage with reference to cancer chemoprevention. Biochem Biophys Res Commun. 2001;288(3):552-7.

22. Frederiks WM, Bosch KS. Localization of superoxide dismutase activity in rat tissues. Free Radic Biol Med. 1997;22(1-2):241-8.

23. Zelko IN, Mariani TJ, Folz RJ. Superoxide dismutase multigene family: a comparison of the CuZn-SOD (SOD1), Mn-SOD (SOD2), and EC-SOD (SOD3) gene structures, evolution, and expression. Free Radic Biol Med. 2002;33(3):337-49.

24. Crapo JD, Oury T, Rabouille C, Slot JW, Chang LY. Copper,zinc superoxide dismutase is primarily a cytosolic protein in human cells. Proc Natl Acad Sci U S A. 1992;89(21):10405-9.

25. Beno I. Staruchova M. Volkovova K. Batovsky M. Increased antioxidant enzyme activities in the colorectal adenoma and carcinoma. Neoplasma. 1995:42(5):265-9.

\section{Correspondence:}

Eva Glória Abrão Siufi do Amaral

Universidade Federal de Mato Grosso do Sul

Cidade Universitária

Campo Grande - MS - Brazil
Conflict of interest: none

Financial source: none

\section{How to cite this article:}

Amaral EGAS, Fagundes DJ, Marks G, Inouye CM. Study of superoxide dismutase's expression in the colon produced by azoxymethane and inositol hexaphosfate's paper, in mice. Acta Cir Bras. [serial on the Internet] 2006;21 Suppl 4. Available from URL: http://www.scielo.br/acb. 